\title{
Strategi Menuju Kampus Berkelanjutan (Studi Kasus: Fakultas Teknik, Universitas Sebelas Maret)
}

\author{
Hakimatul Mukaromah \\ Program Studi Perencanaan Wilayah dan Kota, Fakultas Teknik \\ Universitas Sebelas Maret \\ e-mail: hakimatul.m@ft.uns.ac.id
}

\begin{abstract}
Abstrak - Pembangunan berkelanjutan menjadi acuan dalam arah pembanguna kota yang kemudian didetailkan dalam tujuh belas tujuan pembangunan berkelanjutan (sustainable development goals). Perguruan Tinggi merupakan salah satu elemen dalam sarana perkotaan yang memiliki peran strategis dalam mencapai tujuan keberlanjutan pembangunan melalui konsep kampus berkelanjutan. Tujuan dari penelitian ini adalah untuk menganalisis penerapan konsep kampus berkelanjutan yang dilakukan Fakultas Teknik Universitas Sebelas Maret (FT UNS). Metode yang digunakan adalah mengidentifikasi potensi dan masalah baik internal maupun eksternal yang dihadapi oleh FT UNS dalam penerapan enam komponen kampus berkelanjutan (setting and infrastructure, waste, water, transportation, energy and climate change dan education) dan perumusan strategi dengan menggunakan metode analisis SWOT. Hasil sintesis strategi adalah sebagai berikut: (1) peningkatan anggaran untuk mewujudkan infrastruktur kampus ramah lingkungan (green building) dan dukungan untuk aktivitas P2M berbasis lingkungan atau pembangunan berkelanjutan, (2) perbaikan pada aspek transportasi, yaitu dengan perbaikan pada sistem parkir, dan alternatif moda transportasi massal atau ramah lingkungan, (3) pelibatan seluruh civitas akademik dalam setiap kegiatan terkait pembangunan berkelanjutan, dan (4) peningkatan pengelolaan limbah cair dan padat (sampah) dengan menerapkan prinsip keberlanjutan.
\end{abstract}

Kata Kunci-Kampus Berkelanjutan, Pembangunan Berkelanjutan

\section{PENDAHULUAN}

$\mathrm{P}$ EREKEMBANGAN dan pertumbuhan suatu kota seringkali dihadapkan pada berbagai macam tantangan. Salah satunya adalah bagaimana menciptakan harmonisasi antara aspek lingkungan, ekonomi, dan sosial dalam berbagai proses pembanguan suatu kota. Keseimbangan antara ketiga aspek tersebut diharapkan dapat terus terwujud, sehingga diharapkan generasi mendatang dapat ikut memanfaatkan sumber daya yang ada seperti saat ini untuk memenuhi kebutuhannya dimasa mendatang. Untuk itu, arah pembangunan kota saat ini diarusutamakan untuk mencapai 17 Sustainable Development Goals (SDG's). Konsep dan tujuan pembangunan berkelanjutan ini kemudian diturunkan dalam berbagai macam visi, misi, dan kebijakan di seluruh negara dan kota-kota di dunia [1].

Perguruan Tinggi merupakan salah satu elemen dalam sarana perkotaan yang memiliki peran strategis dalam mencapai tujuan pembangunan keberlanjutan melalui konsep kampus berkelanjutan. Konsep kampus berkelanjutan atau green campus memperhatikan tiga aspek, yaitu ekonomi, sosial, dan lingkungan [2]. Konsep ini kemudian diturunkan oleh UI Green Metric untuk menilai usaha kampus untuk mewujudkan kampus yang berkelanjutan melalui serangkaian komponen [3]. Komponen kampus berkelanjutan tersebut adalah: setting and infrastructure, waste, water, transportation, energy and climate change dan education [4].

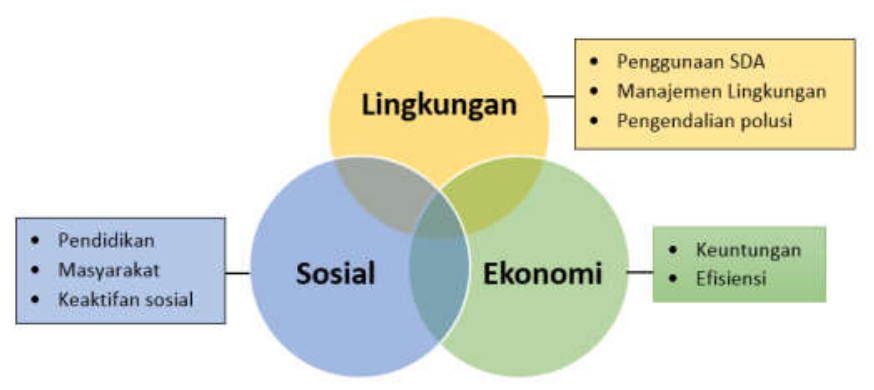

Gambar 1. Komponen Kampus Berkelanjutan

Sumber: [2]-[4]

Keenam komponen tersebut relevan dengan berbagai tujuan yang ingin dicapai dalam SDG's, yaitu [5]:

1. Setting and infrastructure relevan dengan tujuan 9, yaitu terkait peran perguruan tinggi dalam inovasi dan mewujudkan industri yang inklusif dan berkelanjutan serta tujuan ke 11, yaitu terkait perwujudan lingkungan kampus yang inklusif, aman, tangguh, dan berkelanjutan.

2. Waste relevan dengan tujuan 3, yaitu mewujudkan hidup sehat di lingkungan kampus, serta tujuan ke 14, yaitu dalam upaya konservasi laut dengan mengelola limbah yang dihasilkan dalam aktivitas kampus (limbah laboratorium, sampah, dsb.)

3. Water relevan dengan tujuan 6, yaitu mewujudkan pengelolan atau pemanfaatan sumber daya air yang berkelanjutan.

4. Transportation relevan dengan tujuan 13, yaitu upaya menurunkan gas emisi rumah kaca melalui serangkaian kebijakan di bidang transportasi, serta tujuan ke 15, yaitu upaya kampus dalam mengelola lahan (proporsi lahan terbuka hijau dan terbangun, ekosistem kampus, dsb.) yang rentan dengan emisi dari transportasi

5. Energy and climate change relevan dengan tujuan 7, yaitu terkait penyediaan dan pemanfaatan sumber energi yang 
terjangkau dan dapat dimanfaatkan oleh semua kalangan. Selain itu juga relevan dengan tujuan ke 13, yaitu terkait perwujudan perhatian terhadap isu perubahan iklim tidak hanya dalam lingkungan kampus tetapi juga edukasi ke publik secara lebih luas.

6. Education relevan dengan tujuan 4 , yaitu mewujudkan pendidikan yang berkeadilan serta memiliki perhatian terhadap isu-isu lingkungan.

Beberapa hal yang dapat dilakukan perguruan tinggi dalam mewujudkan kampus berkelanjutan antara lain adalah penyusunan rencana pengembangan perguruan tinggi yang berorientasi pada infrastruktur hijau, pelibatan seluruh civitas akademika untuk membentuk komunitas yang berkelanjutan, dan memiliki inisiatif dalam pencarian dana dari berbagai sumber untuk pengembangan riset yang mendukung terwujudnya kampus berkelanjutan [6]. Selain itu perlu diseminasi terkait konsep green campus melalui penelitian dan pengajaran, perhatian terhadap lingkungan bagi seluruh civitas akademik, upaya konservasi sumber daya alam dan mengurangi polutan, serta mengupayakan desain kampus sesuai kebutuhan penggunanya [2].

UNS mulai mengikuti pemeringkatan UI Green etric pada tahun 2013. Pada tahun 2019 UNS mendapatkan peringkat 7 di tingkat nasional dan 97 di dunia [7]. Upaya perbaikan di berbagai komponen terus dilakukan melalui koordinasi tim green campus UNS. Hal ini dapat terlihat dari meningkatknya poin penilaian pada kelima komponen kampus berkelanjutan. Penurunan poin terjadi pada komponen setting and infrastructure, karena adanya penurunan ruang terbuka hijau akibat dari bertambahnya kebutuhan akan ruang untuk aktivitas civitas akademika. Peran serta seluruh civitas akademik di setiap fakultas dalam upaya peningkatan aksi untuk mendukung UNS menjadi kampus berkelanjutan sangat diperlukan. Oleh karena itu, tim green campus UNS secara internal melaksanakan kompetisi yang diikuti oleh seluruh fakultas di lingkungan UNS untuk mendorong setiap fakultas berkontribusi dalam keenam aspek kampus berkelanjutan.

Salah satu fakultas yang unggul di lingkungan UNS adalah fakultas teknik. Selama tiga tahun berturut-turut, dari tahun 2017 sampai dengan 2019, fakultas teknik mendapatkan peringkat pertama dalam penerapan komponen kampus berkelanjutan. Hal ini karena beberapa kegiatan yang dilaksanakan di fakultas teknik memiliki dampak ke seluruh fakultas atau lingkungan UNS secara lebih luas. Kegiatan tersebut antara lain adalah berbagai kerjasama yang diinisiasi oleh fakultas teknik dalam penyediaan IPAL (Instalasi Pengolahan Air Limbah), penyediaan SPAM (Sistem Penyediaan Air Minum) UNS, dan revitalisasi danau UNS. Kegiatan lain adalah terkait berbagai riset yang dikoordinasi oleh tenaga pendidik fakultas teknik seperti pengembangan mobil listrik dan baterai lithium sebagai sumber energy terbarukan.

Peran strategis fakultas teknik dalam penerapan komponen kampus berkelanjutan dapat menjadi pembelajaran di fakultas lain di lingkungan UNS maupun perguruan tinggi lainnya. Disisi lain, penerapan komponen kampus berkelanjutan tersebut membutuhkan evaluasi dan peningkatan untuk menghadapi tantangan yang lebih besar di masa mendatang. Oleh karena itu perlu adanya kajian terkait potensi dan masalah yang dihadapi fakultas teknik baik dari aspek internal dan eksternal, sehingga dapat dirumuskan strategi yang tepat untuk mewujudkan fakultas teknik dan UNS menjadi kampus berkelanjutan.

\section{METODE PENELITIAN}

Penelitian ini menggunakan metode kualitatif. Metode kualitatif menekankan analisis pada upaya mengungkap hal-hal yang terkait dengan proses bukan pada produk. Penggunaan metode ini ditandai dengan penggunaan metode indepthinterviews, mengidentifikasi mekanisme keterkaitan fungsional antar elemen/variabel, dan terakhir melakukan interpretasi terhadap berbagai sumber data atau informasi [8]. Ketiga penciri metode kualitatif tersebut akan digunakan dalam penelitian ini.

Untuk memperkuat validasi data kualitatif yang digunakan, penelitian ini menggunakan triangulasi tiga sumber data, yaitu data dari observasi lapangan, data yang diperoleh melalui wawancara dengan stakeholders (unit umum dan keuangan fakultas, dosen, dan mahasiswa), dan data sekunder yang diperoleh dari masing-masing unit dalam fakultas.

Tahapan pertama dalam penelitian adalah mengidentifikasi penerapan keenam komponen kampus berkelanjutan berdasarkan komponen dari UI Green Metric 2019, yaitu: setting and infrastructure, waste, water, transportation, energy and climate change dan education. Indikator dari masingmasing komponen yang digunakan dalam penelitian ini adalah [4]:

1. Setting and infrastructure, meliputi: rasio antara ruang terbuka dengan total area kampus dan populasi kampus serta persentase anggaran untuk upaya keberlanjutan.

2. Waste, meliputi: program daur ulang sampah, program untuk mengurangi penggunaan kertas dan plastik, pengolahan limbah organik, anorganik, dan beracun.

3. Water, meliputi: program konservasi air, pemanfaatan air daur ulang, dan penggunaan peralatan hemat air.

4. Transportation, meliputi: jumlah kendaraan, layanan shuttle kampus, kebijakan kendaraan bebas emisi, rasio area parkir dan total area kampus, program transportasi untuk membatasi area parkir, inisiatif untuk mengurangi kendaraan pribadi, dan kebijakan jalur pejalan kaki.

5. Energy and climate change, meliputi: penggunaan peralatan hemat energi, sumber energi terbarukan di dalam kampus, total penggunaan listrik, rasio produksi energi terbarukan dengan penggunaan energi, program pengurangan emisis gas rumah kaca

6. Education, meliputi: mata kuliah terkait keberlanjutan, publikasi ilmiah terkait keberlanjutan, kegiatan terkait keberlanjutan, dan organisasi kemahasiswaan terkait keberlanjutan.

Tahap kedua yaitu mengidentifikasi kekuatan dan kelemahan serta merumuskan strategi menggunakan metode analisis SWOT (Strength, Weakness, Opportunity, Threat). Metode analisis SWOT digunakan untuk menganalisis kelebihan dan 
kekurangan dari faktor internal dan eksternal serta dapat digunakan untuk perumusan strategi atau kebijakan dengan melihat faktor strategis [9]. Faktor internal meliputi strength dan weakness yang ada dalam lingkungan fakultas teknik, sedangkan faktor eksternal adalah opportunity dan threat yang berasal dari luar lingkungan fakultas teknik, dapat berupa isu atau kebijakan dari universitas atau kebijakan dari luar universitas.

\section{HASIL DAN DISKUSI}

\section{A. Identifikasi Penerapan Kampus Berkelanjutan}

Fakultas Teknik UNS telah melaksanakan berbagai program terkait penerapan kampus berkelanjutan pada berbagai aspek. UNS sebagai bagian dari anggota UI GreenMetric World University Rankings Network melalui Sekretariat Green Campus mendorong setiap fakultas untuk melaksanakan dan melakukan inisiatif dalam implementasi konsep kampus berkelanjutan. Berikut adalah hasil identifikasi penerapan enam komponen kampus berkelanjutan:

\section{1) Setting dan Infrastrucutre}

Dalam kurun waktu 2019, Fakultas Teknik telah menganggarkan kurang lebih $15,2 \%$ dari total anggaran. Anggaran tersebut khusus untuk pengadaan fisik terkait green building, diantaranya adalah: pengadaan solar cell, pembuatan taman, instalasi charger mobil listrik, pemisahan instalasi listrik, perbaikan cat gedung, pembuangan sampah, lampu hemat energy, shower otomatis, dan renovasi gedung.

Luas area fakultas teknik adalah 5,54 $\mathrm{Ha}$, dengan area terbangun 2,89 Ha dan area non terbangun 2,65. Penambahan ruang terbuka hijau dengan adanya vertical garden di beberapa gedung juga dilakukan. Vertical garden tidak hanya berfungsi sebagai tambahan RTH tetapi juga berfungsi ganda untuk aspek estetika dan penghalang sinar matahari yang terlalu berlebihan di beberapa ruang. Upaya penambahan RTH juga dilakukan dengan adanya sentralisasi kantin (dari 3 kantin menjadi 1 kantin dengan 2 lantai).

Prinsip K3L (Kesehatan, Keselamatan, Keamanan dan Lingkungan) juga sudah diterapkan dalam lingkungan Fakultas Teknik. Hal ini dapat dibuktikan dengan adanya gugus tugas $\mathrm{K} 3 \mathrm{~L}$ yang bertanggung jawab dalam penerapan prinsip-prinsip K3L dalam setiap kegiatan di Fakultas Teknik. Beberapa kegiatan yang dilakukan adalah: pemutaran video atau safety induction di setiap acara/kegiatan, simulasi pemadam kebakaran, dan penyediaan alat-alat K3L di setiap gedung di lingkungan Fakultas Teknik.

\section{2) Waste}

Pengelolaan sampah di Fakultas Teknik secara umum terbagi menjadi dua jenis, yaitu untuk sampah organik dan anorganik. Pengelolaan sampah diawali dengan penyediaan tempat sampah yang terpisah sesuai kedua jenis sampah tersebut. Selanjutnya, sebagian sampah organik akan didaur ulang di rumah kompos. Pengelolaan rumah kompos diserahkan pada himpunan mahasiswa pecinta alam fakultas. Disisi lain, sampah anorganik disalurkan ke pihak ketiga untuk dimanfaatkan kembali.

Pengelolaan sampah organik menjadi kompos mulai aktif kembali di tahun 2019 setelah terhenti selama beberapa tahun. Inisiasi dimulainya kembali pengelolan sampah muncul dari wakil dekan bidang umum dan keuangan yang baru. Faktor kepemimpinan dalam pengelolaan sampah berperan dalam keberlanjutan pengelolaan sampah organik di Fakultas Teknik. Selain itu, terdapat pula inisiatif daur ulang limbah laboratorium, seperti laboratorium beton, yang memanfaatkan limbahnya untuk penataan taman Fakultas Teknik dan pelatihan pembuatan ecobrick.

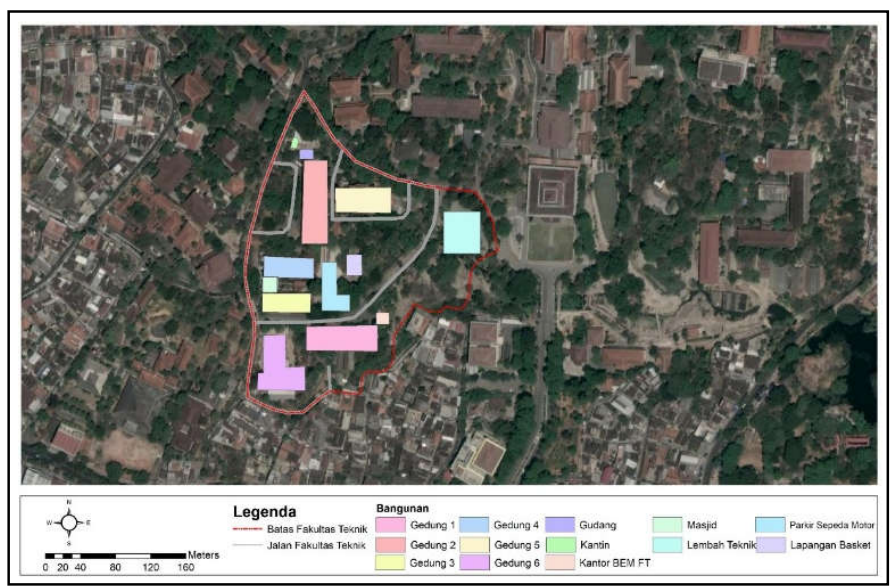

Gambar 2. Peta Fakultas Teknik, Universitas Sebelas Maret

Peran kebijakan dalam pengelolan sampah muncul dengan adanya pembatasan penggunaan kertas dan plastic. Pembatasan penggunaan kertas yang dilakukan adalah: penggunaan kertas bekas dalam disposisi, penggunaan kertas bolak balik untuk dokumen tugas akhir, dan penggunaan SMS gateway atau pesan online untuk meminimalisir penggunaan kertas undangan. Pembatasan penggunaan plastic sekali pakai di fakultas teknik disesuaikan dengan arahan Rektor UNS dalam Surat Edaran Nomor 29/UNS27/SE/2020 tentang Larangan Penggunaan Kemasan Air Minum Berbahan Plastik Sekali Pakai dan/atau Kantong Plastik di Lingkungan Universitas Sebelas Maret [10]. Edaran tersebut antara lain berisi: Penggunaan botol minum dan alat makan pribadi, penyediaan air minum dan snack rapat dengan menggunakan tempat yang dapat dipakai kembali serta menghindari penggunaan plastic dan steriofoam di kantin Fakultas Teknik. Hal-hal tersebut telah diupayakan untuk dilakukan khususnya di lingkungan pengurus fakultas, sedangkan untuk acara/kegiatan yang dilaksanakan mahasiswa atau program studi masih ditemukan penggunaan plastic sekali pakai.

Pengelolaan toxic waste recycling di Fakultas Teknik dikhususkan pada limbah-limbah hasil laboratorium. Laboratorium tersebut antara lain adalah laboratorium Teknik Kimia dan Teknik Elektro. Namun, sampai saat ini pengelolaan limbah berbahaya baru sampai pada perumusan SOP (Standar Operational Procedure) penanganan limbah.

\section{3) Water}

Penggunaan air bersih di Fakultas Teknik bersumber dari 
sumur dalam dengan kapasitas penggunaan sebesar 31.800 L/bulan. Selain melakukan ekstraksi air tanah, Fakultas Teknik juga berupaya untuk melakukan konservasi air dengan dibangunnya kolam pengumpul air hujan dengan luas kurang lebih sebesar $154 \mathrm{~m}^{2}$ dan merevitalisasi Sungai Kendil yang melewati Fakultas Teknik. Fakultas Teknik juga memiliki IPAL (Instalasi Pengolahan Air Limbah) yang merupakan hibah dari Kementerian Pekerjaan Umum dan Perumahan Rakyat. IPAL tersebut berfungsi mengelola air limbah dari seluruh fakultas di UNS dan beberapa rumah tangga di sekitar kampus UNS Surakarta.

Upaya penghematan air yang dilakukan oleh Fakultas Teknik adalah dengan penggunaan peralatan hemat air, antara lain sebagai berikut:

- Toilet ecoflush yang berjumlah 50 buah dari total 91 buah toilet yang digunakan

- Kran otomatis yang berjumlah 1 buah dari total 118 buah kran yang digunakan

Selain itu, upaya penghematan air bersih secara nonfisik dilakukan dengan pemberian himbauan menggunakan stiker penghematan penggunaan air yang ditempel di setiap toilet.

\section{4) Transportation}

Kebijakan transportasi di lingkungan fakultas teknik diantaranya adalah terkait zonasi parkir sesuai dengan Surat Keputusan Dekan Nomor 3258/UN27.08/HK/2018 [11]. Zonasi tersebut berfungsi untuk pembatasan kapasitas kendaraan bermotor di lingkungan fakultas teknik. Kapasitas parkir mobil di Fakultas Teknik adalah 137 dan parkir sepeda motor sejumlah 700 unit dengan luas lahan $2625,5 \mathrm{~m}^{2}$. Proporsi lahan parkir terhadap total keseluruhan luas lahan fakultas teknik adalah $0,05 \%$.

Terdapat tiga jenis kendaraan listrik zero emisi yang dikelola oleh Fakultas Teknik diantaranya adalah sepeda listrik, motor listrik, dan mobil listrik yang masing-masing berjumlah 1 buah. Kendaraan tersebut digunakan untuk keperluan internal kampus dan merupakan hasil riset beberapa dosen di Fakultas Teknik. Pengembangan kendaraan listrik terus dilakukan oleh tim mobil listrik dan tim pengembangan baterai lithium sampai saat ini.

Penggunaan sepeda bagi civitas akademik juga menjadi prioritas. Hal ini dapat dilihat dari penyediaan fasilitas yang mendukung penggunaan sepeda. Fasilitas tersebut adalah tersedianya parkir sepeda di Gedung 3 Fakultas Teknik. Selain itu juga penyediaan toilet dengan shower (khususnya seluruh toilet di lantai 1 setiap gedung di fakultas teknik) untuk mendukung aksi bersepeda dan berjalan kaki ke kampus.

Upaya pengurangan kendaraan bermotor juga dilakukan dengan penyediaan bis kampus yang rutenya melewati seluruh fakultas di UNS termasuk fakultas teknik. Namun, pelayanan bis kampus masih belum optimal dengan waktu tunggu yang cukup lama, yaitu kurang lebih 15 menit. Hal ini karena hanya 1 atau 2 bis saja yang beroperasi setiap harinya.

\section{5) Energy and climate change}

Upaya penghematan energy listrik di lingkungan fakultas teknik dilakukan dengan penggunaan peralatan hemat energi, antara lain:
- $\mathrm{AC}$ inverter yang berjumlah 234 buah dari total 338 buah AC yang digunakan, atau sekitar $65 \%$.

- Lampu LED yang berjumlah 1.928 buah dari total 2.110 buah kran yang digunakan, atau sekitar $90 \%$.

- Automatic Lighting di toilet kantor fakultas

Selain itu, upaya penghematan energy juga telah dilakukan dengan meminimalisir penggunaan lampu dan $\mathrm{AC}$ melalui penghawaan alami dan pencahayaan alami dengan adanya jendela di setiap ruang yang bisa dibuka, kampanye hemat listrik melalui stiker, kontrol penggunaan ruang atau listrik oleh petugas keamanan yang berkeliling secara berkala dan melalui CCTV.

Produksi dan penggunaan energi terbarukan di lingkungan fakultas teknik adalah dengan pemanfaatan solar cell. Pemasangan solar cell memanfaatkan atap koridor penghubung gedung 1 dan gedung 3 serta sebagian dari atap area parkir sepeda motor. Total solar cell yang telah terpasang adalah kapasitas $15.000 \mathrm{~W}$ dan menghasilkan daya listrik sebesar 20 kwh perhari. Energi listrik dari solar cell digunakan untuk kebutuhan listrik untuk lampu di gedung 3 dan gedung 4. Jika dibandingkan dengan rata-rata penggunaan listrik per hari adalah $2294 \mathrm{kwh}$, maka energy dari solar cell baru dapat memenuhi $1 \%$ dari total kebutuhan.

\section{6) Education}

Dari total 12 program studi S1 dan D3 di fakultas teknik, hanya 3 program studi yang tidak memiliki mata kuliah terkait lingkungan atau keberlanjutan. Namun, materi terkait green campus telah dimasukkan dalam materi pengenalan kampus bagi mahasiswa baru, sehingga diharapkan mahasiswa memiliki perhatian terhadap kondisi lingkungan sekitarnya.

Kegiatan seminar, workshop, dan kegiatan lain terkait lingkungan rutin dilaksanakan baik oleh mahasiswa maupun dosen. Kegiatan-kegiatan tersebut cenderung meningkat setiap tahunnya, seperti terlihat pada tabel 1 . Hal ini menunjukkan adanya perhatian yang meningkat pada isu-isu lingkungan.

Tabel 1.

Kegiatan Civitas Akademika FT UNS terkait Lingkungan

\begin{tabular}{cc}
\hline \hline Tahun & Kegiatan terkait Lingkungan \\
\hline 2017 & 9 kegiatan \\
2018 & 10 kegiatan \\
2019 & 17 kegiatan \\
\hline \hline
\end{tabular}

Arahan Penelitian dan Pengabdian Masyarakat (P2M) bagi tenaga pendidik terkait lingkungan dan perubahan iklim telah masuk dalam rencana induk penelitian UNS 2016-2020 [12]. Outputnya adalah terdapat publikasi karya ilmiah dari tenaga pendidik fakultas teknik terkait lingkungan pada jurnal ilmiah adalah 51 judul dan pada proceeding seminar sejumlah 12 judul.

\section{B. Perumusan Strategi Menuju Kampus Berkelanjutan}

Berdasarkan hasil identifikasi penerapan setiap komponen kampus berkelanjutan yang telah dilakukan di Fakultas Teknik, maka dapat disintesis kelebihan, kekurangan, potensi, dan ancaman sebagai berikut: 
Tabel 2.

Daftar SWOT

\begin{tabular}{|c|c|}
\hline Kode & Uraian \\
\hline \multicolumn{2}{|c|}{ Strength/Potensi } \\
\hline S1 & $47 \%$ area fakultas teknik adalah non terbangun \\
\hline $\mathrm{S} 2$ & Ada upaya dalam penambahan ruang terbuka hijau \\
\hline S3 & Pengelolaan sampah organik menjadi kompos \\
\hline S4 & Pemanfaatan kembali limbah laboratorium \\
\hline S5 & Proporsi area parkir hanya $0,05 \%$ dari total area FT \\
\hline S6 & fasilitas bagi pejalan kaki dan pesepeda \\
\hline S7 & $\begin{array}{l}\text { Pengadaan peralatan hemat energi dan air dilakukan } \\
\text { secara bertahap setiap tahun }\end{array}$ \\
\hline & $75 \%$ program studi memiliki mata kuliah berbasis \\
\hline S8 & lingkungan \\
\hline S9 & $\begin{array}{l}\text { Kegiatan pendidikan di bidang lingkungan terus } \\
\text { meningkat setiap tahun }\end{array}$ \\
\hline \multicolumn{2}{|c|}{ Weakness/Kelemahan } \\
\hline W1 & $15,2 \%$ alokasi \\
\hline W2 & ahan sampah anorganik \\
\hline W3 & ste belum maksimal \\
\hline W4 & hemat air masih mini \\
\hline W5 & rogram reuse air bekas pakai wudhu \\
\hline W6 & $\begin{array}{l}\text { Pemanfaatan kendaraan zero emisi untuk aktivitas } \\
\text { internal kampus masih sangat terbatas }\end{array}$ \\
\hline W7 & $\begin{array}{l}\text { Pemanfaatan energi solar cell hanya } 1 \% \text { dari total } \\
\text { kebutuhan listrik per hari }\end{array}$ \\
\hline \multicolumn{2}{|c|}{ Opportunity/Kesempatan } \\
\hline $\mathrm{O} 1$ & $\begin{array}{l}\text { Kerjasama dengan pihak ketiga dalam pengolahan } \\
\text { sampah }\end{array}$ \\
\hline $\mathrm{O} 2$ & $\begin{array}{l}\text { Kebijakan universitas dalam pembatasan penggunaan } \\
\text { plastik sekali pakai }\end{array}$ \\
\hline $\mathrm{O} 3$ & Tersedianya IPAL UNS \\
\hline & Kerjasama penelitian \\
\hline $\mathrm{O} 4$ & kendaraan zero emisi dan baterai lithium \\
\hline & P2M terkait lingkungan menjadi salah satu tema \\
\hline O5 & prioritas dalam rencana induk penelitian UNS \\
\hline O6 & $\begin{array}{l}\text { UNS telah memiliki masterplan menuju kampus } \\
\text { berkelanjutan }\end{array}$ \\
\hline \multicolumn{2}{|c|}{ Threat/Ancaman } \\
\hline $\mathrm{T} 1$ & $\begin{array}{l}\text { Keterbatasan area parkir untuk kegiatan non rutin } \\
\text { (rapat, wisuda, dsb.) }\end{array}$ \\
\hline $\mathrm{T} 2$ & $\begin{array}{l}\text { Kebijakan penggunaan bis kampus belum optimal } \\
\text { dari aspek ketepatan waktu dan ketersediaan armada }\end{array}$ \\
\hline
\end{tabular}

Berdasarkan hasil sintesis SWOT pada tabel 2, maka dapat dirumuskan strategi menuju kampus berkelanjutan sesuai pada tabel 3 .

Berdasarkan perumusan strategi pada tabel 3, dapat disintesis tiga strategi utama, yaitu: (1) peningkatan anggaran untuk mewujudkan infrastruktur kampus ramah lingkungan (green building) dan dukungan untuk aktivitas P2M berbasis lingkungan atau pembangunan berkelanjutan. Strategi ini merupakan hasil sintesis dari strategi W6.W7.O4 dan strategi W1.W4.W7.O4. Peningkatan anggaran tidak hanya berasal dari anggaran internal fakultas, namun juga membuka peluang untuk bekerjasama dengan pihak pemerintah pusat/daerah, swasta, NGO, alumni atau instansi lain. Fakultas Teknik pernah bekerjasama dengan Kementerian Pekerjaan Umum dan Perumahan Rakyat dalam pengadaan IPAL UNS, revitalisasi danau UNS, dan SPAM UNS. Kerjasama lain dalam bidang penelitian juga pernah dilakukan, salah satunya adalah dengan
Toyota dalam penelitian mobil hybrid dan semi hybrid.

Tabel 3.

Rumusan Strategi

\begin{tabular}{|c|c|c|}
\hline & $\begin{array}{l}\text { Opportunity/Kesemp } \\
\text { atan }\end{array}$ & Threat/Ancaman \\
\hline $\begin{array}{l}\text { Weakness/ } \\
\text { Kelemahan }\end{array}$ & $\begin{array}{l}\text { W6.W7.O4: Inisiatif } \\
\text { untuk bekerjasama } \\
\text { dalam P2M dengan } \\
\text { pihak swasta lainnya } \\
\text { W2.O2: Penegakan } \\
\text { kebijakan } \\
\text { penggunaan limbah } \\
\text { plastik untuk } \\
\text { meminimalisir } \\
\text { sampah anorganik } \\
\text { W1.W4.W7.O4: } \\
\text { Peningkatan dan } \\
\text { anggaran dan/atau } \\
\text { inisiatif dam } \\
\text { pencarian dana untuk } \\
\text { mendukung kampus } \\
\text { berkelanjutan dari } \\
\text { sumber lain } \\
\text { W3.O1.O3: } \\
\text { Peningkatan } \\
\text { teknologi IPAL UNS } \\
\text { untuk mengelola } \\
\text { toxic waste atau } \\
\text { kerjasama dengan } \\
\text { pihak ketiga dalam } \\
\text { pengelolaan toxic } \\
\text { waste } \\
\text { W5.O6: Pemanfataan } \\
\text { air bekas wudhu di } \\
\text { masjid fakultas teknik } \\
\text { untuk pemenuhan air } \\
\text { bersih non konsumsi }\end{array}$ & $\begin{array}{l}\text { W6.T2.: Peningkatan } \\
\text { kualitas pelayanan bis } \\
\text { kampus sehingga dapat } \\
\text { menurunkan } \\
\text { penggunaan kendaraan } \\
\text { bermotor pribadi } \\
\text { W6.T2: Penyediaan } \\
\text { kendaraan zero emisi } \\
\text { yang dapat diakses } \\
\text { secara gratis oleh } \\
\text { seluruh civitas } \\
\text { akademika }\end{array}$ \\
\hline $\begin{array}{l}\text { Strength/ } \\
\text { Potensi }\end{array}$ & $\begin{array}{l}\text { S8.O5: Mendorong } \\
\text { keterlibatan } \\
\text { mahasiwa dalam } \\
\text { kegiatan terkait } \\
\text { lingkungan, untuk } \\
\text { membentuk } \\
\text { komunitas yang } \\
\text { berkelanjutan } \\
\text { S9.O5: Mendorong } \\
\text { kegiatan P2M tenaga } \\
\text { pendidik yang } \\
\text { bertema lingkungan } \\
\text { atau pembangunan } \\
\text { berkelanjutan } \\
\text { S2.S5.O6: } \\
\text { Pembatasan } \\
\text { penggunaan kendaran } \\
\text { bermotor pribadi di } \\
\text { area kampus dengan } \\
\text { pengadaan parkir } \\
\text { komunal di titik } \\
\text { gerbang kampus }\end{array}$ & $\begin{array}{l}\text { S2.S5.T1: Penyediaan } \\
\text { parkir komunal lebih } \\
\text { dari } 1 \text { lantai }\end{array}$ \\
\hline
\end{tabular}

Strategi yang kedua adalah perbaikan pada aspek transportasi, yaitu dengan perbaikan pada sistem parkir, dan 
alternatif moda transportasi masal atau ramah lingkungan. Strategi ini merupakan hasil sintesis dari strategi W6.T2; S2.S5.O6; dan S2.S5.T1. Aspek transportasi menyumbang gas emisi rumah kaca $(\mathrm{CO} 2)$ terbesar kedua setelah listrik [13]. Perbaikan pada sistem transportasi, selain bermanfaat untuk mengurangi polusi gas $\mathrm{CO} 2$, juga dapat memberikan pengaruh positif pada pengurangan kebutuhan parkir, sehingga dapat meningkatkan luas area non terbangun.

Strategi yang ketiga adalah pelibatan seluruh civitas akademik dalam setiap kegiatan terkait lingkungan atau pembangunan berkelanjutan. Strategi ini merupakan hasil sintesis dari strategi S8.O5 dan S9.O5. Perwujudan kampus berkelanjutan membutuhkan peran masyarakat yang berkelanjutan (sustainable society) [6]. Oleh karena itu, sosialisasi, edukasi dan pelibatan seluruh civitas akademik, termasuk tenaga pendidik, tenaga kependidikan, cleaning service, dan mahasiswa, dalam setiap komponen kampus berkelanjutan perlu ditingkatkan.

Strategi yang terakhir adalah peningkatan pengelolaan limbah cair dan padat (sampah) dengan menerapkan prinsip keberlanjutan. Strategi ini merupakan hasil sintesis dari strategi W2.O2; W3.O1.O3; dan W5.O6. Pengelolaan sampah yang berkelanjutan yaitu pengelolaan dengan menerapkan prinsip 3R (reduce, reuse, and recycle) [14]. Pengelolaan limbah cair yang berkelanjutan adalah dengan menggunakan teknologi yang tepat sesuai tingkat pencemaran limbah, selain itu juga dapat berupa pemakaian kembali air bekas pakai untuk kegiatan non konsumsi seperti agrikultur (penyiraman) [15].

\section{KESIMPULAN}

Fakultas Teknik merupakan salah satu bagian dari Universitas Sebelas Maret yang unggul dalam penerapan konsep kampus berkelanjutan. Namun, masih ditemukan beberapa hal berupa kelemahan dan ancaman yang diidentifikasi. Oleh karena itu perlu adanya perumusan strategi dalam peningkatan perwujudan konsep kampus berkelanjutan untuk menjawab tantangan di masa mendatang. Berdasarkan perumusan strategi dapat dilihat bahwa secara umum memerlukan: (1) peningkatan anggaran untuk mewujudkan infrastruktur kampus ramah lingkungan (green building) dan dukungan untuk aktivitas P2M berbasis lingkungan atau pembangunan berkelanjutan, (2) perbaikan pada aspek transportasi, yaitu dengan perbaikan pada sistem parkir, dan alternatif moda transportasi masal atau ramah lingkungan, (3) pelibatan seluruh civitas akademik dalam setiap kegiatan terkait pembangunan berkelanjutan, dan (4) peningkatan pengelolaan limbah cair dan padat (sampah) dengan menerapkan prinsip keberlanjutan.

\section{DAFTAR PUSTAKA}

[1] United Nation, Sustainable Development Goals. [Online]. Available: https://www.un.org/sustainabledevelopment/

[2] R. M. Mahayudin, M. Y. M. Yunos, M. A. O. Mydin, O. M. Tahir, "Developing a Sustainable Campus Landscape Criteria: An Evaluation Universiti Pendidikan Sultan Idris as a Green Campus," Adv. Environ. Biol., 9(4), 201-204, (2015).
[3] E. Lourrinx, Hadiyanto, M. A. Budihardjo, "Implementation of UI GreenMetric at Diponegoro University in order to Environmental Sustainability Efforts," E3S Web of Conferences 125, 02007 (2019)

[4] UI Green Metric, "Petunjuk UI GreenMetric World University Rankings," (2019).

[5] R. Y. Hamzah, N. W. Alnaser, W. E. Alnaser, "Accelerating the transformation to a green university: University of Bahrain experience E3S Web of Conferences," 48, 06002 (2018).

[6] G. A. Kristanto, C. Priadi, N. Suwartha, E. Bahsan, A. Udhiarto, "Lessons learned in developing a green environment at the Engineering Faculty, University of Indonesia MATEC Web of Conferences," 101, 04008 (2017).

[7] Kampus Berkelanjutan. [Online]. Available: https://greencampus.uns.ac.id/kampus-berkelanjutan/

[8] H. S. Yunus Metode Penelitian Wilayah Kontemporer. Yogyakarta: Pustaka Pelajar (2016).

[9] L Muta'ali, "Teknik Analisis Regional," Yogyakarta: Badan Penerbit Fakultas Geografi UGM (2015).

[10] Surat Edaran Rektor UNS Nomor 29/UNS27/SE/2020 tentang Larangan Penggunaan Kemasan Air Minum Berbahan Plastik Sekali Pakai dan/atau Kantong Plastik di Lingkungan Universitas Sebelas Maret.

[11] Surat Keputusan Dekan Nomor 3258/UN27.08/HK/2018 tentang Zonasi Parkir.

[12] Rencana Induk Penelitian UNS 2016-2020. [Online]. Available: https://lppm.uns.ac.id/wp-content/uploads/2019/07/Rencana-IndukPenelitian-UNS-2016-2020.pdf

[13] B. Ridhosari, A. Rahman, Carbon Footprint Assessment At Universitas Pertamina From The Scope Of Electricity, Transportation, And Waste Generation: Toward A Green Campus And Promotion Of Environmental Sustainability," Journal of Cleaner Production Volume 246 (2020).

[14] A. V. Shekdar, "Sustainable Solid Waste Management: An Integrated Approach For Asian Countries," Waste Management Volume 29, Issue 4, April (2009), Pages 1438-1448.

[15] S. C. Jhansi, S. K. Mishra, "Wastewater Treatment and Reuse Sustainability Options Consilience,” No. 10 (2013), pp. 1-15. 